Thus did the experiments of Charlesworth and Conolly confirm the principles of treatment inaugurated by Daquin and Pinel; and prove that the best guide to the treatment of lunatics is to be found in the dictates of an enlightened and refined benevolence. And so the progress of science, by way of experiment, has led men to rules of piactice nearer and nearer to the teachings of Christianity. To my eyes a pauper lunatic asylum, such as may now be seen in our English counties, with its pleasant grounds, its airy and cleanly wards, its many comforts, and wise and kindly superintendence, provided for those whose lot it is to bear the double burthen of poverty and mental derangement-I say this sight is to me the most blessed manifestation of true civilisation that the world can present.

This result we owe to the courage and philanthropy of such men as Pinel and Conolly. Pinel's large acquirements and practical intellect would alone have availed nothing; his first step would never have been taken but for the generous impulses of a feeling heart and courageous spirit. Conolly's experiment at Hanwell would have been foiled by opposition and discouragement, had he not been sustained by a spirit of earnest benevolence towards his unhappy patients.

The spirit which animated these two men is the spirit without which much of the progress of practical medicine would have been impossible. For, however diverse may be the intellectual powers that find their several fit places in the study and practice of medicine, there is but one right temper for it - the temper of benevolence and courage ; the temper in which Larrey invented the ambulances volantes, that he might bring help to the wounded under fire; the temper in which phyeicians have devoted themselves to the study of the plague and other infectious fevers; that same temper which has originated and sustained the highest Christian enterprises, and which ennobles any man who, possessing it, with an honest and true heart does bis duty in our profession.

\title{
The Association for the Promotion of Social Science.
}

The Association for the Promotion of Social Science has excited something of opposition and ridicule by the very largeness of its pretensions. The word "social" and the word "science" are among the nost comprehensive in the language, and the scope of each is not lessened by its union with the other. When, then, a number of ladies and gentlemen met together some years since to "promote" social science, the discerning part of the public guessed that the result would be the delivery of a great number of

certaine liberté de faire qu'il puisse se livrer mésurément anx impulsions que la nature lui commande; ce qu'on à très bien compris et éxecuté aux Hôpitaux de Bethlém et de Saint-Luc à Londres."

Daquin, in his essay already referred to, when treating of the construction of asplums, adds in a note :- " Il y à Londres l'hôpital de Bethléem où les fous sont traités avec toute l'humanité et tons les soins imaginables, et à Manchester on en a bâti un depuis peu, où, d'apres le compte qui en a été rendu, les succes ont été étonnans." "

In 'Observations on Insanity,' by John Haslam, Apothecary to Bethlehem Hospital, 1798, the moral treatment recommended is kindly and not unwise. (I have not seen the edition of 1794.) It seems as if the treatment of Lunatics in Bethlehem Hospital had deteriorated between the end of the last century and the time of the Parliamentary inquiry in 1814. The period was one in which the thoughts and energies of England were engrossed in war.

According to Daquin (op. cit.), the knights of Malta were accustomed to treat their insane patients with gentleness and kindness. If 80 , they were not altogether degenerate representatives of their once famous order. 
erratic essays on things in general, with, probably, very little indeed of true scientific thought or method. Successive meetings have confirmed this foreboding, and we are afraid that, though the association may become every year more social, it will become less scientific. But we have never had a doubt that such an annual assembling is likely to do a great deal of good. If it were called an association for earnest and philanthropic conversation, it would be rightly named. There is a good, utilitarian, Penny Magazino purpose about the members which deserves all praise, and they do talk about things which are very important, and on which it is desirable that people should exchange opinions. The Association will probably bring forth a few new ideas, and popularise others that are too little known. It will encou. rage people to write an essay about some matter which they understand, since they will be secure of getting an audience, and will not have the trouble of finding a publisher. But chiefly it will have the effect of enlisting many who have leisure in the cause of practical welldoing. One of the strongest impulses among those who have affluence, combined with a certain measure of ability, is to find some philanthropic works which shall recommend itself to their reason more than almsgiving, or worrying the poor by visitings. A great good may be achieved by making such persons sensible that there is a field for systematic benevolence,- that there are sound principles on which they can confer the greatest amount of happiness on the greatest number. To make observations, to collect statistics, to attack abuses, to cause apathy, to agitate against bad laws and to study the principles of better ones, are labours in which thousands of prosperous and not overworked people in these islands can combine, and from which they would derive more satisfaction than from their present often misdirected efforts.

The Association has, we think, no reason to regret the choice of the president for the present year. Lord Brougham, with his wide and receptive mind, his encyclopædic reading, and his appreciation of every form of knowledge, represented rather the weakness of the Association than its strength. His discourses "de omni re scibili" had a tendency to encourage his admiring followers to disquisitions on everything that can affect mortality. As abstracts of what had been achieved by the human race during the year before and what ought most to engage the attention during the year to come they were excellent, but they were dangerous guides to ambitious ladies or young gentlemen with a turn for omniscience. On the other hand we have seldom read a more useful "inaugural address" than that of Lord Shaftesbury. The tendency of it is to correct the faults which most easily beset the institution over which he presides. Lord Shaftesbury has had the good sense to confine himself to a single subject, one which he thoroughly understands, and on which his remarks will have the weight due to experience and recorded achievements. With singular force and eloquence he depicted the state of the working people of this country, and showed how much remains to be done before it is possible that they should become healthy, moral, and enlightened. After giving the association the praise that duly belongs to it-that of disseminating and popularising correct notions on matters of great importance, such, for instance, as the treatment of the epidemic which has lately visited us, and after having encouraged his friends to persevere, even though their ideas might not meet immediately with success, Lord Shaftesbury devoted himself to the most practical of all practical questions, - the condition of this vast labouring class of whom we hear 80 much, but of whom even those who directly employ them know so little. Since be began his labours many years ago there has been, indeed, a mighty change. The "great condition of England question" has pretty well settled itself, intolerable distress and its concomitant, ferce discontent, have passed away. The scenes which saddened the early years of the present reign are 
not likely ever to reappear. In those days humane men felt that the enjoyment of their own prosperity was made impossible by the sufferings around them. Railways and free-trade, by trippling the commerce of the country, have removed the greatest of these evils; and we have the comfort of feeling that future struggles will be easy in comparison with those through which we have passed. The danger, indeed, is that we should fancy that little now remains to be done. There is a general chorus of gratulation on the "state of the nation," that frightful topic of the old times. Every speaker and writer point out that the wages are rising, that the produce of taxes yearly increases, that mechanical science is preparing a millennium in which there shall be richer people than ever. It is a good thing that some one should rise now and then to tell us that this progress is not universal, or rather that in the general advance the weak and the halting are trodden down by the onward rush. It may be too much to say that the poorest class, for which Lord Shaftesbury pleads, has made no advance, but what is a positive progress may be a relative retrogression, and certainly the state of hundreds of thousands, particularly in our great towns, appears more dismal than ever, through being contrasted with the comfort and even luxury to which the classes above them have become accustomed. There is, first, the pest of ignorance. With all that has been done, the children of the poirr are not educated. Education has been the cry of the age as long as any but old men can remember, and yet there is the fact that a large proportion even of the young adults cannot read, much less write. This is a subject on which every one who speaks seems to be afraid of committing himself, and we have no desire to propose any solution of our own. But we may say that we do not believe that the ignorance of the working classes, urban or rural, arises either from theological jealousy among their teachers, or from the apathy of an aristocratic legislature. If there be any fact clearly es. tablished, it is that there are money and teachers forthcoming to give every child in the three kingdoms an excellent education. The whole machinery is ready ; nothing is wanted but the power to compel attendance. Lord Shattesbury understands the matter too practically to rail at the House of Commons, which has done all that public opinion would allow it to do. $\mathrm{He}$ shows that it is the demands of labour which take the child away from the school. Though everywhere that instruction has been combined with work, as in the half.time system, it is found that the work is better done, yet the greed of parents and the pitiless demands of employers refuse to spare the scholar for the school. This is the real difficulty, and until public opinion allows the State to interfere and claim the tender mind as its own, there will be no thorough education in England. The same power which protects the woman and the child from excessive or unfit labour in certain trades must be wielded before the young can be delivered from ignorance.

Yet even this protection from prostrating toil is very inefficiently given and Lord Shaftesbury, turning to another branch of his subject, says, - "I appeal to you on behalf of $1,400,000$ children, women, and young persons still under the slavery of cruel and oppressive trades, who are to this hour without the pale of legislative protection. While I leave the remainder, I must dwell for a moment on the abomination of the brickfields. . . . There the female seems to be brought to the lowest point of servile ignorance and degradation. Hundreds of little; girls from eight to eleven years of age, half naked, and so besmeared with dirt as to be barely distinguishable from the soil they stand on, are put to work in these abodes of oppression. Bearing prodigious burdens of clay on their heads or in their arms, they totter to and fro during many hours of toil." Such is England at the present hour. It is clear that here, too, the nation must consent to enlarge the powers of the State before the evil can be effectually met. We may call 
attention to another part of the address, because the opinion of the speaker coincides with that which we have frequently expressed. Lord Shaftesbury attributes the moral as well as the physical mischiefs which beset the lowest class to the wretched state of the dwellings in which they live. That typhus and cholera, and general permanent debility, should be caused by a narrow and undrained lodging is obvious enough, but it is not every one that perceives how drunkenness, profligacy, and general moral degradation, are directly the consequences of choked rooms, filthy smells, and the want of the appliances of cleanliness. That such is the case, however, is beyond a doubt. The craving for gin is the almost inevitalle result of living in a vitiated atmosphere, and long experience has convinced the most persevering schoolmasters that it is almost impossible to educate children who inhabit the worst kind of courts. Here are certainly facts, not only for the Social Science Association, but for Parliament, and they all seem to point one way-that is, in the direction of more efficient State control. The most stalwart partisans of laissez faire must be shaken in their creed when they consider these things. It may be that we shall have to approach to Continental usages in many of these matters. How far, and by what machinery, are questions which the Social Science people might well consider.-The Times, October 6th.

\section{Psychological Experts.}

Ir is the fashion to say that medical men in general are not good witnesses. The recent case of Hunter $v$. Sharpe, at least, lends no support to such a theory. The medical evidence for the defence was admirably given; where all were good it would seem invidious to mention names, but Dr. Williams's evidence was especially noticeable. The masterly way in which the questions of counsel were met, and the clearness and force with which the points were brought forward, reflect much credit upon the scientific witnesses engaged. If psychological experts were as careful and as exact we should not so often see the contempt of juries for their opinion, exhibited by verdicts opposed to their evidence. We hope to have seen the last of "sensation" lunacy trials; should one again arise, let the experts imitate in their manner of giving evidence the careful precision, the calm, unbiassed manner, and the knowledge of the subject,' shown by the medical witnesses in the late cause.-The Lancet, December 8th.

\section{Lunatics at Home.}

If the Commissioners of Lunacy should be induced to supplement the asylum system of England by the farming lunatics in private dwellingsand the deficiency of existing accommodation has been so murked for some time that we have before been induced to recommend that course-one thing must necessarily and inmediately follow - a great addition to the inspecting power of the board. At present lunatics in dwellings are practically uninspected in England; that is to say, they are not inspected more than once a year, and if in the house of a relative not at all. Chancery lunatics only are, under such circumstances, inspected four times annually. It is the characteristic danger of the cottage and private house system, that it lends itself very readily to abuse. The history of Scottish lunatics showed this very fully ; and, until lately, the grossest abuses existed where lunatics were confined in private dwellings in that country. A more perfect system of 